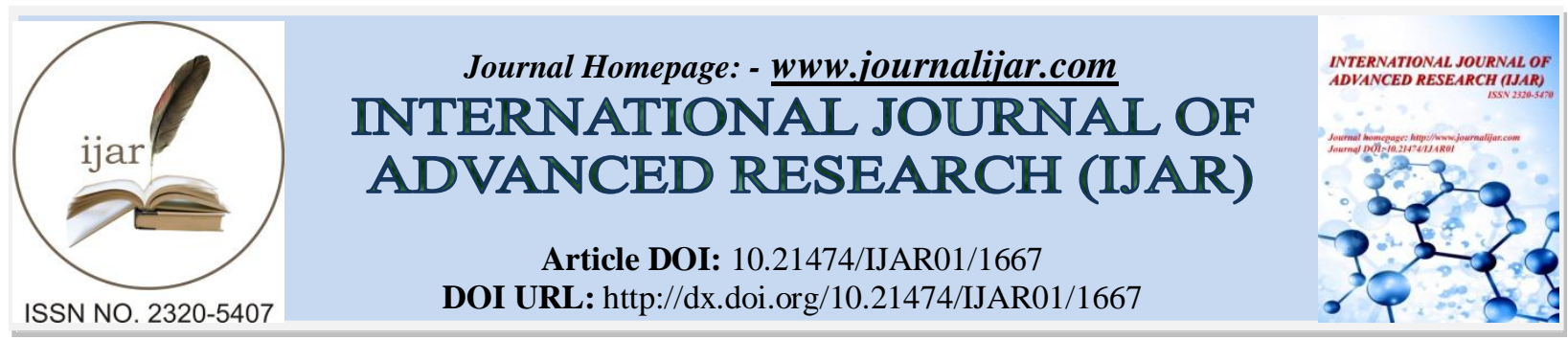

RESEARCH ARTICLE

\title{
EFFECT OF HYDRATION TREATMENTS ON KEEPING QUALITY OF GERBERA FLOWER.
}

Metta. Siresha ${ }^{1}$ and Mahalakshmi V. Reddy ${ }^{2}$.

1. Research Scholar, Department of Resource Management and Consumer Science, College of Home Science, Acharya N.G. Ranga Agricultural University, Guntur, AP, India.

2. Professor and Head, Department of Resource Management and Consumer Science, College of Home Science, PJTSAU, Saifabad, Hyderabad, Telangana, India.

\section{Manuscript Info}

\section{Manuscript History}

Received: 16 July 2016

Final Accepted: 19 August 2016

Published: September 2016

\section{Key words:-}

Seasonal flower, Hydration treatment, Vase Life, Floral Preservatives, Silver thiosulphate (STS)

\section{Abstract}

An experimental study was conducted to study the effect of hydration treatments on gerbera flower. Gerbera is one of the most commonly used for decorations. These flowers start withering and perish within few hours, unless cared after post harvest. With the timely treatment, these flowers can regain its freshness with suitable hydration treatment. Six preservatives were identified and selected which are most commonly used for different flowers during hydration process for the study. The changes were observed for ten days in the quality of the flowers. These were qualitatively evaluated by three experts for change in colour, form, texture and appearance. Results emerged out of the study revealed that STS and SBW treatments had significant influence on the keeping quality.

Copy Right, IJAR, 2016,. All rights reserved.

\section{Introduction:-}

Flowers are living things and need proper care and handling. Keeping quality of a flower depends on the type of stem it has. They can be woody, hollow, soft, firm, bulbous and latex producing. Flowers pre-treated in a hydrating solution and then placed in a holding solution have a higher vase life, increase flower opening or prevent damage from ethylene. Hydrating solutions encourage water uptake by reducing water $\mathrm{pH}$ (acidifying agent; Dole and Wilkins, 2005). Gerbera is one of ten popular cut flowers in the world and according to the trends in floriculture. Here the flowers are not only big, but they also are heavy and has hollow stem. Those heavy blossoms put a strain on the very delicate stems. Though flowers won't usually snap off the stems, but they will bend it to the point the blossom is floppy where as stem bending varied from 0 to $100 \%$ between different cultivars (Javad, et.al, 2011). Uncared Gerbera petals bruise easily, turn brown and shrivel a bit. Those brown petals look unsightly in an arrangement. The treatments can improve vase life may be confined by the plant genome (Nowak and Plich, 1981; Waters, 1964). The use of preservative solutions is regarded as a common practice for the storage of floral stems. These treatments allow to control ethylene synthesis, pathogen development, maintenance of hydric and respiration balance, to contribute to colour conservation. (Arboleda 1993, Halevy \& Mayak 1981). A commercial floral preservative contain a combination of compounds that provide a food source for fresh cut materials (carbohydrate) and reduces the bacterial growth (antimicrobial agent) which maintains the freshness in the container (McDaniel, 1996). These treatments also reduced ethylene production by about $56 \%$ and delayed the peak of ethylene production by 8 to 11 days. This study was taken up with an objective to explore hydration preservatives suitable for increasing the vase life of Gerbera flower.

Corresponding Author:- Metta. Siresha.

Address:- Research Scholar, Department of Resource Management and Consumer Science, College of

Home Science, Acharya N.G. Ranga Agricultural University, Guntur, AP, India. 


\section{Materials and Methods:-}

Experimental research design was adopted for conducting the study. This experiment was designed to test the preservative treatments from commonly available solvents when compared to solutions prepared with commercial solvents. This research was taken up in the Floral Craft Production Unit of the Department of Resource Management and Consumer Sciences in the month of March 2012. Fresh Gerbera Flowers were procured for experiments from wholesale market, also stems were trimmed and placed in the hydration solutions for about ten days at room temperature. A total of 3 trials were conducted with six preservatives. The Treatments identified for preservation of flowers were C: Control; $\mathrm{T}_{1}$ (STS); $5 \mathrm{ml}$ of Silver thiosulphate to a half liter of Water; $\mathrm{T}_{2}$ (SBW): Sprite 50ml, Bleach $1.5 \mathrm{gms}$ to a liter of warm water to a half liter; $\mathrm{T}_{3}(\mathrm{AW})$ : Aspirin $1 \mathrm{gm}$ to a half liter of warm water; $\mathrm{T}_{4}$ (LSBW): Lemon Soda 50ml,Bleach 0.7gms to a half liter of Water; $\mathrm{T}_{5}$ (SBLW): Sugar 2gm, Bleach 1.5gm, Listerine Mouth Wash $6 \mathrm{ml}$ to a half liter of Water; $\mathrm{T}_{6}$ (EBSW): Epsom Salt 2gm, chlorine bleach 2gm, Lemon Soda 50ml to a half a of liter water. Several different ways that may prolong and preserve the flowers. Flowers in water tends to decay and create ethylene gas that speeds flowers to wilt, floral arrangement should be placed in a cool, draft -free area, away from direct sunlight. A total of seven flowers were selected for each trial out of this one was used as control and another set of six were used for hydration treatments. Flowers were allowed to stand in the preservative treatments for maximum period of 10 days. These flowers were evaluated by three experts using a structured evaluation sheet. Good quality flowers suitable for hydration treatment were trimmed for desired length of 8". Flowers were transferred to pre-labelled containers for hydration. These were placed in the cool corner of the room, away from direct sunlight or artificial light. Care was taken to maintain good ventilation. A cut flower needs simple vase solutions which contain acid to improve water flow in flower stems, sugar to help buds open and last longer, and a preservative to reduce growth of bacteria. The physical observations were further supported by photos of the seven flowers until all the flowers had died or drooped.

Parameters to assess the quality of flower: Flowers were evaluated on four variables viz., change in colour, change in form, change in texture and change in appearance. Qualitative rating scale of 1-3 scores were used to measure the variables for each characteristic. The trails were conducted in triplicate for each treatment the nine sample observations were taken by identified expert panel of judges. The experiments were retained till they were not amenable for the study for a period of ten days. The scores obtained for each of these variables were subjected to FTest Two-Sample for Variances and t-Test: Paired Two Sample for Means to study the effect of treatments on vase life of flower.

\section{Results:-}

The physical observation scores collected in terms of scores obtained on colour, form, texture and appearance are tabulated in Table 1. These values are summated scores on four qualitative variables. The end of vase life is usually considered when flowers were wilted, dried out, dropped or become an unpleasant colour. The physical observation data presented in Table1 shows the effect of preservatives on the keeping quality of flowers. It can be noted that irrespective of the preservatives, all the seven experimental flowers remained fresh till second day, with and without treatments (Plate 2). The treatment with $\mathrm{T}_{1}$ and $\mathrm{T}_{2}$ held the flower fresh up to 3 day while $\mathrm{T}_{3}, \mathrm{~T}_{4}, \mathrm{~T}_{5}, \mathrm{~T}_{6}$ resulted in changed colour in the tips of the petals and had slowly transformed into darker shade. The marked change in flowers in $\mathrm{T}_{3}, \mathrm{~T} 4, \mathrm{~T} 5, \mathrm{~T}_{6}$ and $\mathrm{C}$ can be observed in Plate 1 . From these observations, it can be inferred that flowers which have delicate structure, needs additional care with appropriate preservatives to increase their shelf life. Nowak and Rudnicki (1990) inferred that flowers need floral preservative mixture of ingredients added to the water.

Table 1:- Effect of Hydration Treatment on Physical Observation Score of Gerbera.

\begin{tabular}{|c|c|c|c|c|c|c|c|}
\hline Days & Control & T1 & T2 & T3 & T4 & T5 & T6 \\
\hline Day 1 & 12 & 12 & 12 & 12 & 12 & 12 & 12 \\
\hline Day 2 & 12 & 12 & 12 & 12 & 12 & 12 & 12 \\
\hline Day 3 & 8 & 12 & 12 & 9 & 8 & 9 & 10 \\
\hline Day 4 & 4 & 12 & 8 & 4 & 4 & 4 & 4 \\
\hline Day 5 & - & 12 & 8 & - & - & - & - \\
\hline Day 6 & - & 12 & - & - & - & - & - \\
\hline Day 7 & - & 12 & - & - & - & - & - \\
\hline Day 8 & - & 12 & - & - & - & - & - \\
\hline Day 9 & - & 12 & - & - & - & - & - \\
\hline Day 10 & - & 12 & - & - & - & - & - \\
\hline
\end{tabular}

Treatments: C: Control; T1: STS; $T_{2}$ : SBW; $\mathrm{T}_{3}$ : AW; $\mathrm{T}_{4}$ : LSBW; T5: SBLW; $\mathrm{T}_{6}$ : EBSW 
Table 2:- Assessment of Qualitative characteristics of flowers.

\begin{tabular}{|l|c|c|c|c|c|c|c|c|}
\hline Characteristics & Control & T1 & T2 & T3 & T4 & T5 & T6 & T7 \\
\hline Colour & 29 & 36 & 24 & 24 & 19 & 19 & 19 & 19 \\
\hline Form & 22 & 36 & 29 & 20 & 20 & 18 & 19 & 18 \\
\hline Texture & 29 & 32 & 30 & 19 & 18 & 19 & 18 & 19 \\
\hline Appearance & 29 & 32 & 30 & 19 & 19 & 18 & 18 & 19 \\
\hline
\end{tabular}

These Physical observation scores were statistically analyzed to establish the influence of treatments on number of days to retain the qualities of flowers and are presented in Table 3. The quality of the flowers deteriorated significantly from the fourth day onwards (Plate 2), where as in $\mathrm{T}_{1}$ it remained fresh up to10 days (F-Test TwoSample for Variance). Among treatments, treatment $\mathrm{T}_{1}$ (STS) was found to have significant difference over other treatments (t-Test: Paired Two Sample for Means) for period of 10 days, thus the null hypothesis is rejected.

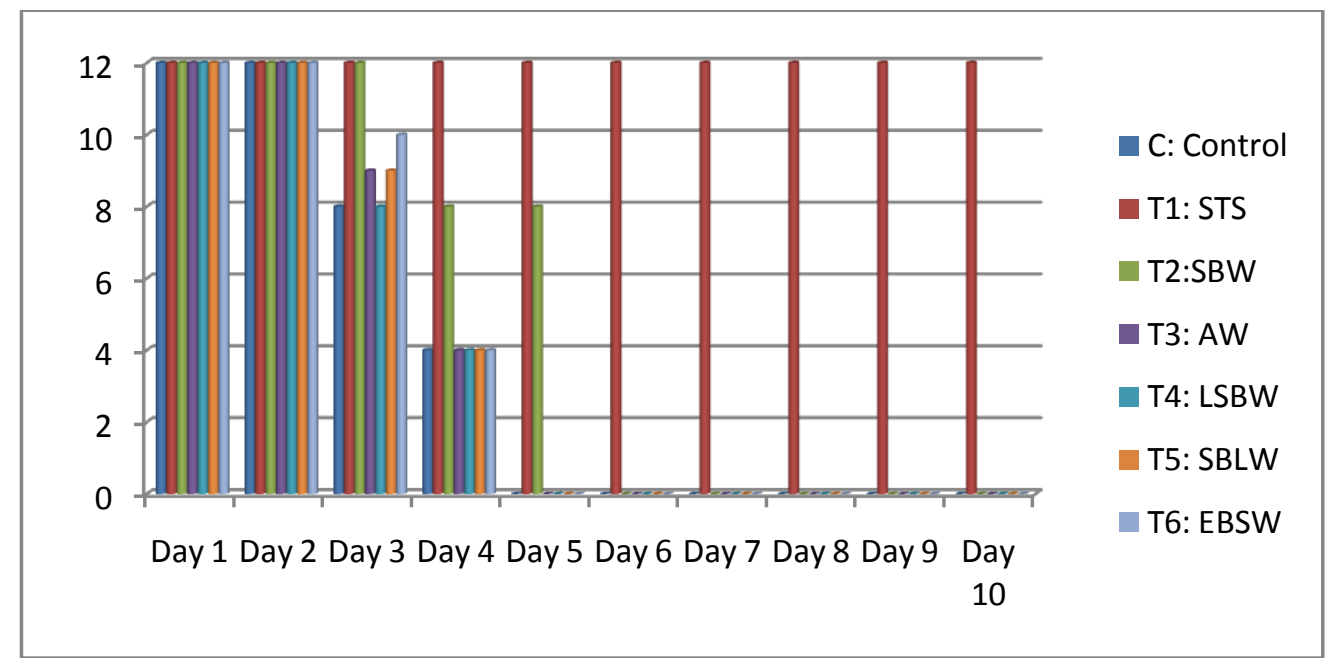

Plate 1:- Effect of Hydration Treatments on the keeping quality of Gerbera.

As Gerbera stems are highly susceptible to bacteria blockage, causing their heads to droop over and are particularly sensitive to ethylene gas to causing flower senescence or abscission of petals and buds. STS treatment was found to be effective to minimize damage to Gerbera. This chemical composition was developed by blending Silver Nitrate and Sodium Thiosulphate ( Leiv \& Hans2005; Paul 1996; Singh and Bhattacharjee 2000), the chemical preservatives which controls higher antibacterial properties and suppress stem bending more effectively STS is markedly effective in extending the vase life of many cut flowers including carnation, Delphinium (Ichimura et al. 2002, Uda et al. 1997, Reddy and Kumari (2009).

Table 3:- F test and t- Test of Physical Observation score of Gerbera.

\begin{tabular}{|l|c|c|}
\hline \multicolumn{3}{|c|}{ F-Test Two-Sample for Variances } \\
\hline & Day 3 & Day 4 \\
\hline Mean & 9.714286 & 5.714286 \\
\hline Variance & 2.904762 & 9.904762 \\
\hline Observations & 7 & 7 \\
\hline Df & 6 & 6 \\
\hline F & 0.293269 & \\
\hline P(F<=f) one-tail & 0.080543 & \\
\hline F Critical one-tail & 0.233434 & \\
\hline
\end{tabular}

\begin{tabular}{||l|c|c|}
\hline \multicolumn{3}{|c|}{ t-Test: Paired Two Sample for Means } \\
\hline Day 4 & CONTROL & $T 1$ \\
\hline Mean & 4 & 11.66667 \\
\hline Oariance & 4.5 & 0.5 \\
\hline Peservations & 9 & 9 \\
\hline $\begin{array}{l}\text { Hypothesized Mean } \\
\text { Difference }\end{array}$ & 0 & \\
\hline Df & 8 & \\
\hline t Stat & -10.2859 & \\
\hline $\mathrm{P}(\mathrm{T}<=\mathrm{t})$ one-tail & $3.44 \mathrm{E}-06$ & \\
\hline $\mathrm{t}$ Critical one-tail & 1.859548 & \\
\hline $\mathrm{P}(\mathrm{T}<=\mathrm{t})$ two-tail & $6.87 \mathrm{E}-06$ & \\
\hline $\mathrm{t}$ Critical two-tail & 2.306004 & \\
\hline
\end{tabular}



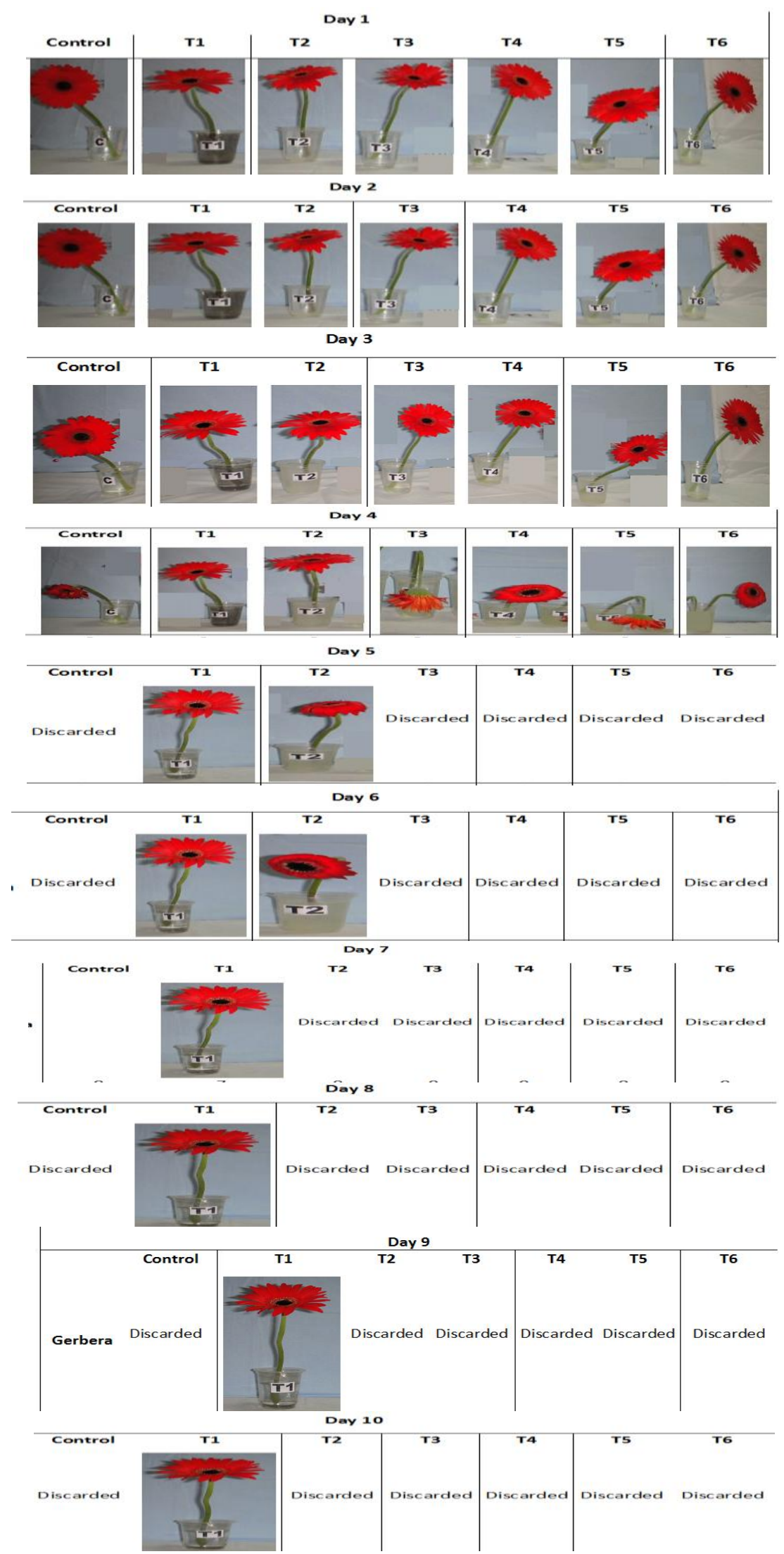

Plate 2:- Effect on Floral Preservatives on Keeping Quality of Gerbera Flower. 
Physical characteristics of flowers have potential influence on the acceptance of flower for multiple uses. The data stated in Table -2 has proved the positive effect of STS treatment on the colour, form, texture and appearance.

It is interesting note that the next best option for preservation of Gerbera was $\mathrm{T}_{2}$ which is a homemade preservative, evolved with a combination Sprite and bleach in water. This combination is a chemical blends of saccharine, citric acid, biocide which is also very effective in curbing the damage. Fernando et.al., (2009), Sooch et al., (2002) and McDaniel, (1996). Biocides like chlorine, sodium hypochloride bromine to control the growth of bacteria. As all flower stems have bacteria and fungi on them. These micro organisms feed on the sugar which is in the flower and then they multiply and blocks the ends of the stem for the flower. Without a biocide, the life of flowers is shortened very quickly.

\section{Conclusion:-}

Flower quality is adversely affected due to inadequate postharvest care facilities and procedures. Hydrating is the process by which water and other ingredients are introduced into flowers to make them turgid, flower life generally increases by 25 to $75 \%$ or more. Flowers benefit from hydration solutions. At the same time, almost no flower is harmed from their use. This study was taken up with an objective to explore hydration preservatives suitable for increasing the vase life of Gerbera flower. Experimental research design was adopted to conduct the study. This experiment was designed to test the preservative treatments from commonly available solvents at home level and commercial solvents. Flowers were evaluated on four variables viz., change in colour, change in form, change in texture and change in appearance. Observation data collected in terms of scores obtained on colour, form, texture and appearance in summated scores on four qualitative variables. The scores obtained were analysed through F-Test Two-Sample for Variances and t-Test: Paired Two Sample for Means to study the effect of treatments on vase life of Gerbera flower. Results emerged out from the study were $T_{1}$ (Silverthiosulphate) was found to be effectual formulation over the other formulations and it retained its freshness for ten days, while $T_{2}$ retained freshness up to five days with the simple homemade preservative i.e., the blend of sprite, bleach in warm water. They contain acid to improve water flow in flower stems, sugar to help buds open and last longer, and a preservative to reduce growth of bacteria and fungi which coincides with Clark et.al, (2010).

Florists try hard to keep the flowers in good condition. The flower preservatives explored in this study are inexpensive and easily accessible; hence, entrepreneurial spirits of flower enthusiasts may continue to flourish. This study would be helpful and interesting to the homemakers who decorate the tables beautifully with flower as table arrangements and keep the interiors refreshing so these arrangements can be preserved to increase the vase life of the fresh flowers and makes them cheerful.

\section{References:-}

1. Arboleda J A (1993) Principios fundamentales de la postcosecha de flores. En: Tercer Seminario Técnico de Floriculture: 93: 11-14.

2. Clark, Erin M R, Dole, John M, Carlson, Alicain S, Moody, Erin P, McCall, Ingram F, Fanelli, Frankie L, Fonteno and William C (2010). Vase Life of New Cut Flower Cultivars. HortTechnology, 20: 1016-102

3. Dole J M and H F Wilkins (2005) Floriculture: Principles and species, $2^{\text {nd }}$ ed. Pearson Education Inc. Upper Saddle River, New Jersey. 202-203.

4. Fernando de la R, Pilar C M, Juan E Á and Miguel U (2009) Treatment with Peracetic Acid Extends the Vase Life of Lisianthus (Eustoma grandiflorum) Flowers. Horticulture Science, 44(2): 418-420.

5. Halevy A H and Mayak S (1981) Senescence and postharvest physiology of cut flowers, Part 2. Horticultural Reviews, 3: 59-143.

6. Ichimura K, Kawabata, M Y, Kishmoto R, Goto and Yamad K (2002) Variation whit the cultivar in the vase life of cut flowers. Natl. Inst. Flor. Science, 2: 9-20.

7. Javad N M, Mostafa K A A and Roya K (2011) Postharvest evaluation of vase life, stem bending and screening of cultivars of cut gerbera (Gerbera jamesonii Bolus ex. Hook f.) Flowers. African Journal of Biotechnology, $10(4), 560-566$.

8. McDaniel G L (1996) Floral Design and Arrangement. $3^{\text {rd }}$ ed. Prentice Hall. Upper Saddle $\quad$ River, $\quad$ New Jersey, 56. 
9. Nowak J and Plich H (1981) Regulation of bud opening, storage period, vase-life, and senescence of cut flowers II The effect of silver ions and other anti-ethylene agents on ethylene synthesis and senescence of gerbera inflorescences. Res. Inst. Pomol. Floricult. Annu. Rpt. 2:10-21.

10. Nowak 1 and Rudnicki R M (1990) Postharvest handling and storage of cut flowers, florist greens and potted plants. Timber Press, Oregon, 44-48.

11. Paul A K and George L S (1996) The Jordanian Flower Industry: A Production And Postharvest Perspective. Perishables Research Organization, United States Agency for International Development. pp 63-75.

12. Leiv, M.M., Hans, R.G. (2005) Effect of air humidity variation on powdery mildew and keeping quality of cut roses. Scientia Horticulturae, 140: 49-55.

13. Reddy M V and Kumari D R (2009) Assessing the feasibility of preservation of flowers and foliage in freeze drying process and market potential. State Plan Annual Report 2009-2010, ANGRAU, Hyderabad. 11- 12.

14. Sooch M, Singh K, Kumar R and Singh P (2002) Effect of chemicals on vase life of gerbera. Flor. Res. trend in India- Proceeding of National Symposium of Indian floriculture in the New millennium, Lal-Bagh, Bangalore, 25-27 February, 321-322.

15. Singh U C and Bhattacharjee S K (2000) Effect of pulsing with silver nitrate, STS and DMSU on Raktagandha cut roses, J. Orna. Horticulture, 3(2): 131-132.

16. Uda A, Yamanaka M and Fukushima K (1997) Pretreatment effect of novel ethylene inhibitors on extending longevity of carnation, larkspur and sweet pea cut flowers, Kinki Chugoku Agr. Res. 93: 65-70.

17. Waters W E (1964) Influence of chemical preservatives on keeping quality of asters, carnations, chrysanthemums, and gerbera daisies, Proc. Fla. State Hort. Soc, 77:466-470. 